\title{
Immobilization and Assay of Low-Molecular-Weight Phosphomannosyl Receptor in Multiwell Plates ${ }^{1}$
}

\author{
Jack J. Distler, Rita Patel, and George W. Jourdian \\ Departments of Biological Chemistry and Internal Medicine, The Iniversity of \\ Michigan Medical School, Ann Arbor, Michigan 48109
}

Received March 24, 1987

\begin{abstract}
A novel sensitive hinding assay for quantitation of a low-molecular-weight phosphomannosyl receptor $(41-46 \mathrm{~K})$ was devised. The receptor was immobilized by immunochemical means in the wells of polystyrene multiwell plates. The lysosomal enzyme ligand, testicular $\beta$-galactosidase, was added and receptor-bound $\beta$-galactosidase was measured by conventional colorimetric analysis using $p$-nitrophenyl $\beta$-galactoside as substrate. Inhibitors of the binding of $\beta$-galactosidase to the receptor were removed prior to addition of $\beta$-galactosidase and did not interfere with the assay. Low-molecular-weight phosphomannosyl receptor was readily quantitated in the range of 4 to $100 \mathrm{ng}$ of receptor protein. Binding of $\beta$-galactosidase to the receptor was specifically inhibited by $5 \mathrm{~mm}$ mannose 6 -phosphate. The receptor exhibited optimum binding of $\beta$-galactosidase at $\mathrm{pH} 5.7$ and was saturated with $\beta$-galactosidase at 320 munits $/ \mathrm{ml}$ in the presence of $20 \mathrm{mM} \mathrm{MnCl}$. The requirement for $\mathrm{MnCl}_{2}$ was greatly diminished at higher concentrations of $\beta$-galactosidase. Application of the assay procedure to the quantitation of the low-molecular-weight phosphomannosyl receptor in mammalian tissues is discussed. Ci 1987 Academic Press, Inc
\end{abstract}

KEY WORDS: multiwell assay: phosphomannosyl receptor; $\beta$-galactosidase; antibodies.

Uptake of extracellular lysosomal enzymes and intracellular transport of newly synthesized enzymes by mammalian cells is mediated by phosphomannosyl receptors (1). Two species of membrane-associated receptors which recognize mannose 6-phosphate residues have been reported. High-molecular-weight phosphomannosyl receptor (PMR-1,? $M_{\mathrm{r}}$ approximately 215,000 by SDS-PAGE) was originally isolated from bovine liver (2) but has since been isolated

\footnotetext{
' This work was supported by Grant AM 10531 from the National Institute of Arthritis, Metabolic, and Digestive Diseases, National Institutes of Health, and in part by the Arthritis Foundation, Michigan Chapter.

${ }^{2}$ Abbreviations used: PMR-1, high-molecular-weight phosphomannosyl receptor; SDS-PAGE, sodium dodecyl sulfate-polyacrylamide gel electrophoresis; PMR-2, low-molecular-weight phosphomannosyl receptor; Mes, 4-morpholineethanesulfonic acid; RIA, radioimmunoassay; Hepes, 4-(2-hydroxyethyl)-1-piperazineethanesulfonic acid: PBS, phosphate-buffered saline.
}

from several mammalian tissues (1). Lower molecular weight phosphomannosyl receptors (PMR-2) which exhibit molecular weights in the range of $41-46,000$ on SDSPAGE, have been isolated from bovine testes (3), bovine liver, and a transformed macrophage cell line (4).

PMR-2 is immunologically distinct from PMR -1 and requires addition of divalent cations to bind ligand $(3,4)$. It has been suggested that PMR-1 and PMR-2 serve as alternate routes for the targeting of lysosomal enzymes (4).

Studies of the binding characteristics of the lower molecular weight PMR-2 have been hampered by the lack of a suitable assay for its biological activity. The biological properties of PMR-2 have been largely inferred from the capacity of the receptor to bind affinity matrices that contain immobilized proteins and oligosaccharides bearing mannose 6-phosphate residues. These chromato- 
graphic procedures are tedious and require substantial quantities of receptor. Furthermore, PMR-2 canot be adsorbed onto affinity columns from crude extracts that contain high concentrations of binding inhibitors unless the extracts are greatly diluted (3).

We now report a novel binding assay for PMR-2 based on the immunochemical immobilization of receptor in the wells of polystyrene multiwell plates. The assay procedure takes advantage of the propensity of immobilized receptor to bind lysosomal $\beta$ galactosidase. Using this procedure, the characteristics of the binding of lysosomal enzyme to the receptor can be determined. The methodology may be useful for the determination of other receptors that readily dissociate ligand since only a very short time is required to wash the receptor-ligand complex.

\section{MATERIALS AND METHODS}

Phosphomannosyl receptors, PMR-1 and PMR-2, were extracted and purified by affinity chromatography on phosphopentamannose-substituted aminoethyl agarose as previously described $(2,3)$. Traces of PMR-1 were removed from PMR-2 preparations by an additional cycle of affinity chromatography. Affinity-purified bovine testicular $\beta$-galactosidase was prepared by the procedure of Distler and Jourdian (5). A "high-binding" fraction of $\beta$-galactosidase (enriched in enzyme species containing elevated levels of covalently-bound mannose 6-phosphate) was obtained by chromatography on DEAESephacel (6).

Rabbit antisera to PMR-1 (2) and PMR-2 (3) were prepared as described. Constituents of anti-PMR-2 that reacted with PMR-1 were removed by adsorption on a column containing affinity-immobilized PMR-1. PMR-1 $(0.5 \mathrm{mg})$ contained in $1 \mathrm{ml}$ of binding solution $10.5 \mathrm{M} \mathrm{NaCl}, 0.1 \%$ Triton $\mathrm{X}-100,0.02 \% \mathrm{NaN}_{3}$, and $0.05 \mathrm{M}$ sodium Mes buffer, pH 6.0) was applied to a 1 $\times 2-\mathrm{cm}$ column of phosphopentamannosesubstituted aminoethyl agarose. The column was washed with $50 \mathrm{ml}$ of the binding solution described above without Triton X-100. Anti-PMR-2 antiserum (10 $\mathrm{ml})$ was applied to the column at $4^{\circ} \mathrm{C}$ and the column was washed with $10 \mathrm{ml}$ of binding solution lacking Triton X-100. The twofold diluted antiserum did not react with PMR-1 as determined by RIA (7) and a binding assay (2) but retained full activity against PMR-2 in the multiwell assay procedure described below.

Analyses were performed in multiwell Nunc-Immuno Plates I, Intermed Nunc, Denmark. Organic buffers, Hepes and Mes, and affinity-isolated antibody to rabbit IgG (whole molecule, developed in goat) were obtained from Sigma Chemical Co.

Protein content was measured by the procedure of Peterson (8).

Assay Procedure

Step 1: Preparation of antibody coated wells. Wells were coated with a solid-phase second antibody affinity-purified anti-rabbit IgG, to spare the primary antiserum (9). Stock solutions of the second antibody were stored at $-20^{\circ} \mathrm{C}$ in physiological saline at a concentration of $1 \mathrm{mg} / \mathrm{ml}$. One day before assay, stock solutions of the second antibody were diluted to $2.5 \mu \mathrm{g}$ protein $/ \mathrm{ml}$ with PBS, $\mathrm{pH} 8.5$, and each well was filled with the diluted solution. The plate was covered and left at room temperature overnight. Excess antibody was removed by aspiration and the wells were washed twice with solution A (1\% BSA, $0.05 \%$ Tween $20,0.02 \% \mathrm{NaN}_{3}, 0.15 \mathrm{M}$ $\mathrm{NaCl}$, and $0.05 \mathrm{M}$ sodium Hepes, pH 7.2). The primary antiserum, rabbit anti-PMR-2, was diluted 1:400 from the original serum with solution $\mathrm{A}$, and $200 \mu \mathrm{l}$ was added to each well. The plate was covered and incubated at room temperature on a platform rocker (Adams, Nutator) for $2 \mathrm{~h}$. The wells were aspirated and rinsed two times with solution $\mathrm{A}$, and receptor preparations were added as described below. 
Diluted primary antiserum could be stored at $4^{\circ} \mathrm{C}$ for at least 1 week. Diluted antiserum could be reused at least five times without significant loss of receptor-binding capacity.

Step 2: Immobilization of receptor. Solutions of purified PMR-2, or extracts of tissues to be analyzed, were diluted with solution A to a concentration of 20-200 ng receptor protein $/ \mathrm{ml}$ and $200-\mu \mathrm{l}$ aliquots of the appropriate dilutions were added to the wells. Reagent blanks lacking receptor were also prepared.

When crude tissue extracts were analyzed, controls were included to correct for nonspecific binding of $\beta$-galactosidase. In these controls equivalent amounts of crude extract were added to the wells and mannose 6phosphate was added during subsequent application of $\beta$-galactosidase.

The receptor solutions were allowed to incubate on the rocker platform for $2 \mathrm{~h}$ and the wells were again rinsed two times with solution A prior to addition of ligand.

Step 3: Addition of ligand. Stock solutions of high-binding bovine testicular $\beta$-galactosidase $(6-8$ units $/ \mathrm{ml})$ were diluted to 400 munits $/ \mathrm{ml}$ with solution B ( $5 \%$ BSA, $0.05 \%$ Tween $20,0.02 \% \mathrm{NaN}_{3}, 0.15 \mathrm{M} \mathrm{NaCl}, 0.02$ $\mathrm{M} \mathrm{MnCl}_{2}$, and $0.05 \mathrm{M}$ sodium Mes buffer, $\mathrm{pH}$ 5.7) and 100- $\mu$ l aliquots were placed in each well. I wenty-five microliters of $25 \mathrm{~mm}$ mannose 6-phosphate in solution B was added to the control wells described above and $25 \mu \mathrm{l}$ of solution $\mathrm{B}$ was added to the remaining wells. Inorganic phosphate was excluded from the $\beta$-galactosidase since formation of insoluble manganese phosphate resulted in nonspecific retention of $\beta$-galactosidase in the wells. Phosphate was removed from $\beta$-galactosidase preparations, if necessary, by dialysis against 100 vol of $0.05 \mathrm{M}$ sodium Mes, pH 5.7 , containing $0.02 \%$ $\mathrm{NaN}_{3}$. Following incubation of the plate on the rocker platform at room temperature for $2 \mathrm{~h}$, excess $\beta$-galactosidase was removed by alternately (four times) flicking the solution from the wells and flooding the plate with a solution consisting of $0.02 \mathrm{M} \mathrm{MnCl}_{2}, 0.15 \mathrm{M}$ $\mathrm{NaCl}, 0.02 \% \mathrm{NaN}_{3}$, and $0.05 \mathrm{M}$ sodium acetate, $\mathrm{pH}$ 5.7. The final washing procedure was completed within 2 min to minimize dissociation of ligand from the immobilized receptor.

Step 4: Assay of $\beta$-galactosidase. A substrate mixture $(200 \mu \mathrm{l})$ consisting of $0.1 \%$ BSA, $0.15 \mathrm{M} \mathrm{NaCl}, 0.02 \% \mathrm{NaN}_{3}, 0.01 \mathrm{M} p$ nitrophenyl- $\beta$-galactopyranoside and $0.05 \mathrm{M}$ sodium acetate $(\mathrm{pH} 4.3)$ was added to each well. The plates were covered and placed at $37^{\circ} \mathrm{C}$ for $15-20 \mathrm{~h}$. The reaction was stopped by addition of $100 \mu \mathrm{l}$ of $0.5 \mathrm{M}$ glycine$\mathrm{NaOH}, \mathrm{pH} 10$. The contents of the wells were mixed and the absorbance was determined at $400 \mathrm{~nm}$ in a multiwell plate reader or, alternatively, aliquots were removed from each well and the absorbance was determined in a spectrophotometer. One unit of $\beta$-galactosidase was defined as that amount which produced $1 \mu \mathrm{mol} p$-nitrophenol/min.

\section{RESULTS AND DISCUSSION}

Immobilization of PMR-2 in the wells of multiwell plates was accomplished by combination of direct binding of the receptor to the surface of the polystyrene wells and by use of an immunochemical linking system that increased the amount of bound receptor approximately 10-fold. The immunochemical linking system was composed of a primary antiserum that binds PMR-2 and an affinitypurified anti-rabbit IgG antibody (second antibody) that maximized immobilization of the immunoglobulins contained in the primary antiserum.

\section{Primary Antiserum}

Antisera to PMR-2 exhibited cross-reactivity with PMR-1 (3). While the cross-reactivity did not affect the immobilization of purified PMR-2, it prevented specific immo- 
bilization of PMR-2 from solutions containing both PMR-1 and PMR-2. Antibody against PMR-1 was removed from the primary antiserum by passage through a column of affinity-immobilized PMR-1 as described under Materials and Methods. The adsorbed antiserum was suitable for estimation of PMR-2 in mixtures containing each receptor (see Estimation of PMR-2 in tissue extracts below).

PMR-2 could be adsorbed to the surface of the polystyrene wells in the absence of the immunochemical linking system. The amount of PMR-2 bound in this fashion approximated $10 \%$ of the total receptor added to each well (Fig. 1). The amount of nonimmunochemically bound PMR-2 increased with the time the receptor was left in the wells and reached a maximum after 3-5 days. At 5 days the response was of the same magnitude as that obtained in $2 \mathrm{~h}$ using the immunochemical linking system. Immunochemical linking was, therefore, not essential for immobilization of PMR-2 but its use reduced the time required to immobilize the receptor from several days to $2 \mathrm{~h}$. $\Lambda$ ddition-

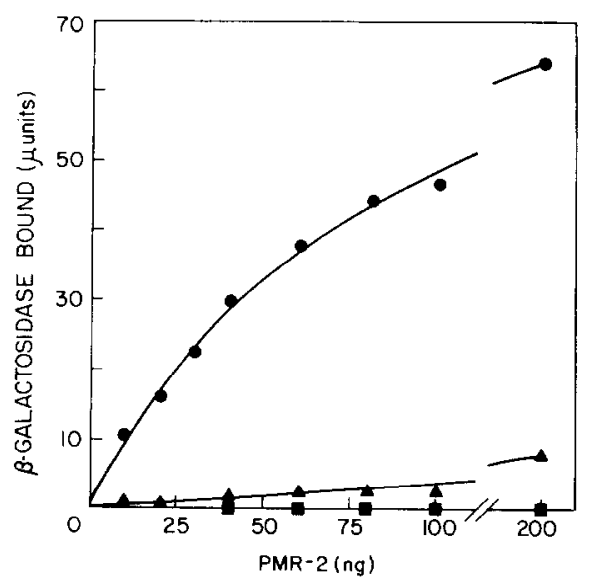

FIG. 1. Effect of PMR-2 concentration on the retention of $\beta$-galactosidase in the multiwell binding assay: (๑) complete assay system; (A) wells not treated with primary antiserum in Step 1; (0), $5 \mathrm{~mm}$ mannose 6phosphate present during incubation with $\beta$-galactosidase in Step 3. ally, use of the antibodies conferred specificity on the type of phosphomannosyl receptor that was immobilized.

\section{Use of Second Antibody}

Pretreatment of the wells with affinity-purified anti-rabbit IgG allowed the use of lower amounts of primary antiserum. For example, when the wells were not treated with the second antibody, 10 times more primary antiserum was required to immobilize an equivalent amount of PMR-2. The optimal amount of second antibody was established by empirical means. When a 10 fold higher concentration of second antibody was applied to the wells, the amount of PMR-2 that was bound was reduced nearly $50 \%$. Presumably, excessive second antibody leads to inactivation of primary immunoglobulins (9).

\section{Binding of $\beta$-Galactosidase to Immobilized PMR-2}

The conditions for the optimal binding of the enzyme ligand to the receptor could be readily determined by modification of the binding medium. Binding of ligand to lowmolecular-weight forms of phosphomannosyl receptor has been suggested to require a divalent cation (3.4). As shown in Fig. 2, the presence of $\mathrm{MnCl}_{2}$ in the medium increased the amount of $\beta$-galactosidase bound to PMR-2 by $50 \%$. The extent of enhancement of ligand binding by $\mathrm{MnCl}_{2}$ was affected by the concentration of $\beta$-galactosidase as shown in Fig. 3. At concentrations of $\beta$-galactosidase above 500 munits $/ \mathrm{ml}$, enhancement of binding by $\mathrm{MnCl}_{2}$ was less than $5 \%$. These results suggest that $\mathrm{Mn}^{2+}$ increases the association constant for the receptor-ligand complex. $\mathrm{MnCl}_{2}(20 \mathrm{mM})$ was used routinely during ligand binding in the multiwell assay since it permitted the use of a lower optimal concentration of $\beta$-galactosidase. $\mathrm{MnCl}_{2}$ was not required for the attachment of antibodies or immobilization of PMR-2 in the wells. In 


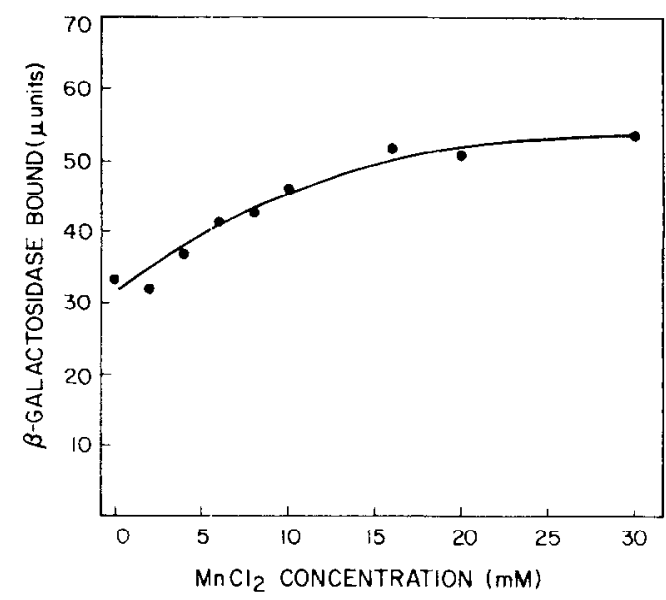

FIG. 2. Effect of $\mathrm{MnCl}_{2}$ concentration on the binding of $\beta$-galactosidase to PMR-2. The multiwell binding assay was performed as described under Materials and Methods except $\beta$-galactosidase was reduced to 150 munits $/ \mathrm{ml}$ in Step 3 to enhance the effect of $\mathrm{MnCl}_{2}$ concentration (ste Fig. 3).

a similar multiwell binding assay performed with PMR-1 and anti-PMR-1 primary antiserum, $\mathrm{MnCl}_{2}$ did not significantly affect binding of $\beta$-galactosidase to PMR-1 (results not shown).

The optimum $\mathrm{pH}$ for binding of $\beta$-galactosidase to PMR-2 was determined by alter-

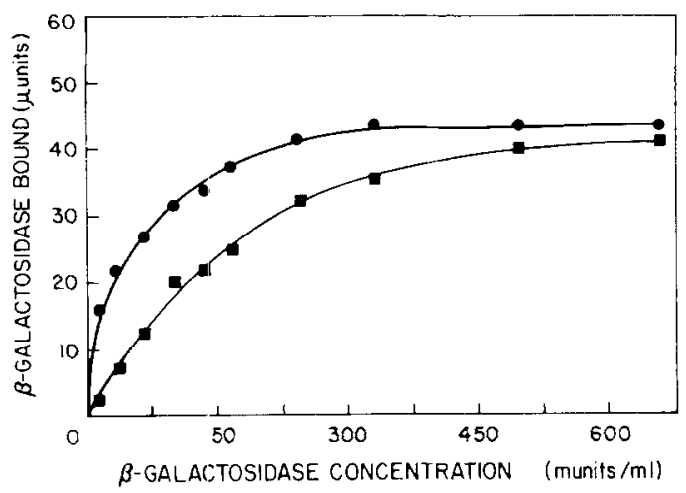

FIG. 3. Effect of $\beta$-galactosidase concentration on the binding of $\beta$-galactosidase to PMR-2. The multiwell binding assay was performed as described under Materials and Methods except that the indicated levels of $\beta$-galactosidase were used in Step $3(\bullet)$ in the presence of $20 \mathrm{mM} \mathrm{MnCl}_{2}$ and ( $\mathbf{D}$ ) in the absence of added $\mathrm{MnCl}_{2}$. ing the $\mathrm{pH}$ of the binding medium (Fig. 4). A $\mathrm{pH}$ of 5.7 was selected for estimations of PMR-2; this $\mathrm{pH}$ value also proved to be optimal for the assay of PMR-1 (results not shown).

\section{Determination of PMR-2}

PMR-2 can be estimated by the multiwell binding assay in the range of 4-100 ng receptor protein/well (Fig. 1). Above this range the response to PMR-2 was reduced, presumably because bound antibody became limiting. Attempts to increase the capacity of the wells to bind PMR-2 by increasing time of incubation and by addition of larger amounts of primary antisera were unrewarding. Maximum immunochemical reaction was achieved in $2 \mathrm{~h}$ and even a 10 -fold increase in primary antiserum resulted in $<10 \%$ increase in the level of PMR-2 bound.

Control wells that contained $5 \mathrm{~mm}$ mannose 6-phosphate did not retain measurable levels of $\beta$-galactosidase when purified PMR-2 was being measured (Fig. 1). However, when crude tissue extracts were exam-

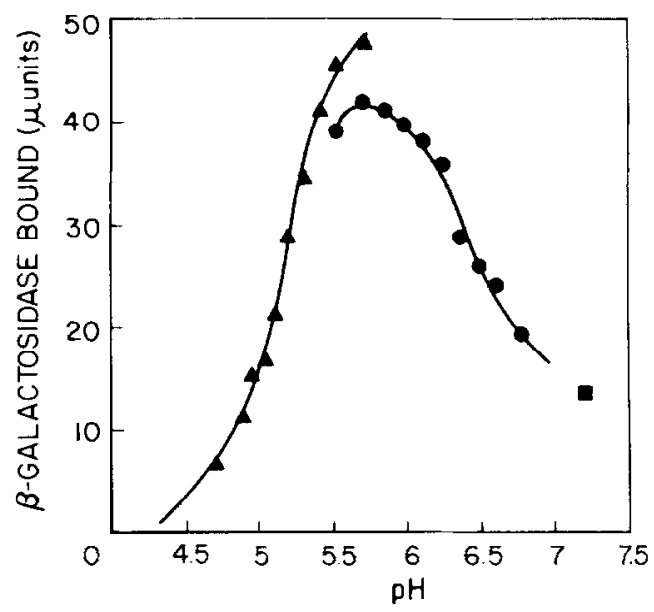

FiG. 4. Effect of $\mathrm{pH}$ on the binding of $\beta$-galactosidase to PMR-2. The multiwell binding assay was performed as described under Materials and Methods except the buffers in the binding medium in Step 3 were $(\Delta) 0.05 \mathrm{M}$ sodium acetate, (•) $0.05 \mathrm{M}$ sodium Mes, and (ם) $0.05 \mathrm{M}$ sodium Hepes at the indicated $\mathrm{pH}$. 
ined, nonspecific binding of $\beta$-galactosidase occurred (see Estimation of PMR-2 in crude tissue extracts). In these instances values obtained in the presence of mannose 6-phosphate were subtracted from those obtained in the absence of mannose 6-phosphate.

\section{Estimation of PMR-2 in Crude \\ Tissue Extracts}

Use of the multiwell assay procedure to estimate PMR-2 in crude tissue extracts is complicated by two factors. First, both PMR-1 and PMR-2 receptors bind to a small extent directly to the polystyrene surface of the wells. Therefore, when mixtures of PMR-1 and PMR-2 are examined by the multiwell procedure, a small amount of $\beta$ galactosidase may be retained in the plate bound to PMR-1. This direct, nonimmunochemical binding of receptor approximates $10 \%$ of the content of either receptor applied to the wells and is not reduced by inclusion of up to $5 \%$ bovine serum albumin in the receptor-immobilization medium. Interference by PMR-1 is somewhat reduced because PMR-1 binds only $17 \%$ of the $\beta$-galactosidase bound by an equivalent amount of
PMR-2 (based on protein content, results not shown).

A second problem with assay of PMR-2 in crude extracts results from nonspecific binding of $\beta$-galactosidase in the wells (retention of $\beta$-galactosidase in the presence of $5 \mathrm{~mm}$ mannose 6-phosphate). This occurs when serum or crude Triton X-100 extracts of tissues have been applied to the wells (Table 1). Frequently a visible film may be seen on the surface of the wells and $\beta$-galactosidase adheres to the residue. The substances responsible for this nonspecific binding of $\beta$-galactosidase have not been identified.

For the reasons described above, crude tissue extracts tend to yield multiwell values for PMR-2 that are higher than those obtained by RIA. However, the multiwell procedure has proved accurate and convenient for monitoring PMR-2 fractions following initial purification steps. The procedure is of particular value for large numbers of samples containing low levels of PMR-2 and for assay of PMR-2 when the biological activity must be determined. In addition, the multiwell assay procedure has been modificd in this laboratory to screen polyclonal and mono-

TABLE 1

FfFfrt of RfGFptor Preparation on B-Galactosidase Immobilization

\begin{tabular}{|c|c|c|c|}
\hline \multirow[b]{2}{*}{ Receptor } & \multirow[b]{2}{*}{ Treatment } & \multicolumn{2}{|c|}{$\beta$-Galactosidase bound ( $\mu$ units/well) } \\
\hline & & Without Man-6-P & With Man-6-P \\
\hline PMR-2 (50 ng) & Complete & 35.1 & $<1$ \\
\hline PMR-2 (50 ng) & Antiserum omitted & 3.5 & $<1$ \\
\hline PMR-1 (250 ng) & Complete & 2.8 & $<1$ \\
\hline PMR-1 (250 ng) & Antiserum omitted & 2.7 & $<1$ \\
\hline Fetal calr serum $(50 \mu 1)^{a}$ & Complete & 10.7 & 7.3 \\
\hline Testes membrane extract $(10 \mu 1)^{h}$ & Complete & 36.7 & 8.2 \\
\hline
\end{tabular}

Note. Solutions were assayed for PMR-2 by multiwell plate assay procedure. The indicatcd amounts of the receptor preparations were added as described in Step 2 under Materials and Methods. Each value was obtained by averaging the results from five wells. Nonspecifically bound $\beta$-galactosidase was measured by inclusion of 5 mM mannose 6-phosphate in Step 3.

${ }^{a}$ Bovine fetal calf serum contained $21.5 \mu \mathrm{g}$ PMR- 1 and $<0.1 \mu \mathrm{g}$ PMR $-2 / \mathrm{ml}$ by RIA procedures $(2,3)$.

${ }^{b}$ Bovine testes cell membrane acetone powder $(5 \mathrm{~g})$ was extracted with $300 \mathrm{ml}$ of a solution containing $1 \%$ Triton $\mathrm{X}-100$ (3). The extract contained $7.7 \mu \mathrm{g}$ PMR-1 and $3.3 \mu \mathrm{g}$ PMR-2/ml by RIA procedures $(2,3)$. 
clonal antibody fractions. In this case the appropriate species-directed anti-IgG second antibody is employed along with the primary anti-PMR-2 immunoglobulins from ascites fluids, or serum samples.

\section{REFERENCES}

1. Jourdian, G. W., Mitchell, D., Maler. T., and Distler. J. (1984) in Molecular Basis of Lysosomal Storage Disorders (Barranger, J. A., and Brady, R. O., Eds.), pp. 195-208, Academic Press, New York.

2. Sahagian, G. G., Distler, J. J., and Jourdian, G. W. (1981) in Methods in Enzymology (Ginsburg, V.. Ed.), Vol. 83, pp. 392-396, Academic Press. New York.

3. Distler, J. J., and Jourdian. G. W. (1987) in
Methods in Enzymology (Ginsburg. V., Ed.), Vol. 138. Academic Press, Orlando. FL. in press. 4. Hoflack, B., and Kornfeld, S. (1985) J. Biol. Chem. 260, 12008-12014.

5. Distler, J., and Jourdian, G. W. (1978) in Methods in Enzymology (Ginsburg, V., Ed.), Vol. 50, pp. 514-520. Academic Press, New York.

6. Sahagian, G., Distler, J., Hieber, V., Schmickel, R.. and Jourdian, G. W. (1979) Fedi. Proc: 38, 467.

7. Mitchell, D. C., Sahagian, G. G., Distler, J. J., Wagner, R. M., and Jourdian, G. W. (1983) in Methods in Enzymology (Fleischer, S., and Fleischer, B., Eds.). Vol. 98, pp. 304-309, Academic Press, New York.

8. Petcrson, G. L. (1977) Anal. Biochem. 83, 346-356.

9. Parsons, G. H. (1981) in Methods in Enzymology (Langone, J., and Van Vunakis, H., Eds.), Vol. 73, pp. 224-239. Academic Press, New York. 